\title{
NONLINEAR OPTICAL RESPONSE OF SMECTIC GLASSES BASED ON COBALT ALKANOATES
}

\author{
A.V. GRIDYAKINA, ${ }^{1}$ YU.A. GARBOVSKIY, ${ }^{2}$ G.V. KLIMUSHEVA, ${ }^{3}$ \\ A.P. POLISCHUK ${ }^{1}$ \\ ${ }^{1}$ National Aviation University of Ukraine \\ (1, Prosp. Komarova, Kyiv 03058, Ukraine; e-mail: morhin@ukr. net) \\ ${ }^{2}$ University of Colorado at Colorado Springs \\ (1420, Austin Bluffs Parkway, Colorado Springs, Colorado, 80918, USA) \\ ${ }^{3}$ Institute of Physics, Nat. Acad. of Sci. of Ukraine \\ (46, Prosp. Nauki, Kyiv 03680, Ukraine)
}

The nonlinear-optical response of anisotropic smectic glasses based on cobalt-alkanoates is studied using the method of dynamic holography. Laser-induced dynamic gratings under the action of nanosecond laser pulses are observed and analyzed for such materials. It is found that a cubic optical nonlinearity of all studied anisotropic glasses is of electronic origin in the nanosecond diapason and caused by a nonlinear polarization of cobalt-alkanoates complexes.

\section{Introduction}

Metal alkanoates $\left(\left(\mathrm{C}_{n} \mathrm{H}_{2 n+1} \mathrm{COO}^{-}\right)_{k} \mathrm{Me}^{k+}\right.$, where $\mathrm{Me}^{k+}$ - metal cation, $\mathrm{C}_{n} \mathrm{H}_{2 n+1} \mathrm{COO}^{-}$- alkanoate-anion, $k=$ $1-3, n \geq 3$ ), can form various states of condensed matter: solid crystalline state, liquid state, liquid crystalline, isotropic and anisotropic glasses [1-4]. Recently, such a variety of metal alkanoates and their phase states was used in order to fabricate optical and nonlinear optical materials, for instance, double-layer cells "photosensitive film - ionic lyotropic liquid crystal" [5], ionic lyotropic liquid crystals doped with electrochromic impurities [5,6], and mesomorphic glasses with dissolved dye molecules [7].

An alternative way of the development of advanced materials is a study of the fundamental properties of pure mesomorphic metal-alkanoates which consist of $d$ and $f$-electron metal ions $[1,8,9]$. Such metal ions are widely used as active centers of laser emission and magnetic, optical and nonlinear-optical materials $[1,9,10]$. Regarding these promising applications, the detailed studies of the physical properties of the transition and rare-earth metal-alkanoates are of the most fundamental and practical importance.

Our previous results show that pure cobalt-decanoate mesomorphic glasses can be used as materials for the pulsed dynamic holographic recording $[8,9]$. In this pa- per, we describe studies of the nonlinear-optical properties of the mesomorphic glasses based on cobaltalkanoates: 1) homologous series of pure cobalt alkanoates; 2) binary and ternary systems based on cobalt|potassium|lithium octanoates.

\section{Materials and Cell Preparation}

\subsection{Materials}

The following types of chemical compounds were used in the studies of nonlinear-optical properties: 1) three representatives of homologous series of cobalt alkanoates $\left.\left(\mathrm{C}_{n} \mathrm{H}_{2 n+1} \mathrm{COO}^{-}\right)_{2} \mathrm{Co}^{2+}(n=7,9,11) ; 2\right)$ binary systems $-\left(\mathrm{C}_{7} \mathrm{H}_{15} \mathrm{COO}^{-}\right)_{2} \mathrm{Co}^{2+} \mid \mathrm{C}_{7} \mathrm{H}_{15} \mathrm{COO}^{-} \mathrm{Li}^{1+}$, 0.5:0.5 molar ratio, and $\left(\mathrm{C}_{7} \mathrm{H}_{15} \mathrm{COO}^{-}\right)_{2} \mathrm{Co}^{2+} \mid \mathrm{C}_{7} \mathrm{H}_{15} \mathrm{COO}^{-} \mathrm{K}^{1+}$, 0.5:0.5 molar ratio; 3) ternary system $\left(\mathrm{C}_{7} \mathrm{H}_{15} \mathrm{COO}^{-}\right)_{2} \mathrm{Co}^{2+}\left|\mathrm{C}_{7} \mathrm{H}_{15} \mathrm{COO}^{-} \mathrm{Li}^{1+}\right| \mathrm{C}_{7} \mathrm{H}_{15} \mathrm{COO}^{-}$ $\mathrm{K}^{1+}$, 0.5:0.25:0.25 molar ratio.

As was shown in our previous works, all studied materials form the liquid crystal state (Smectic A) [11, 12] under melting. It should be noted that the abovementioned liquid crystalline materials can be easy vitrified under cooling. Such a vitrified state can be considered as the "frozen" liquid crystal state and is stable for a long time at room temperature (in fact, samples are still in the glass state even after 1 year after their preparation) [12]. For this reason, the studied glasses are anisotropic and can be called "mesomorphic glasses" in contrast to the well-known isotropic glasses.

\subsection{Cell preparation}

Sandwich-like cells (cell thickness $d_{\text {cell }}=30-100 \mu \mathrm{m}$ ) were filled with the studied liquid crystalline materials at a hot plate at temperatures $T>T_{\mathrm{C}-\mathrm{LC}}\left(T_{\mathrm{C}-\mathrm{LC}}-\right.$ 


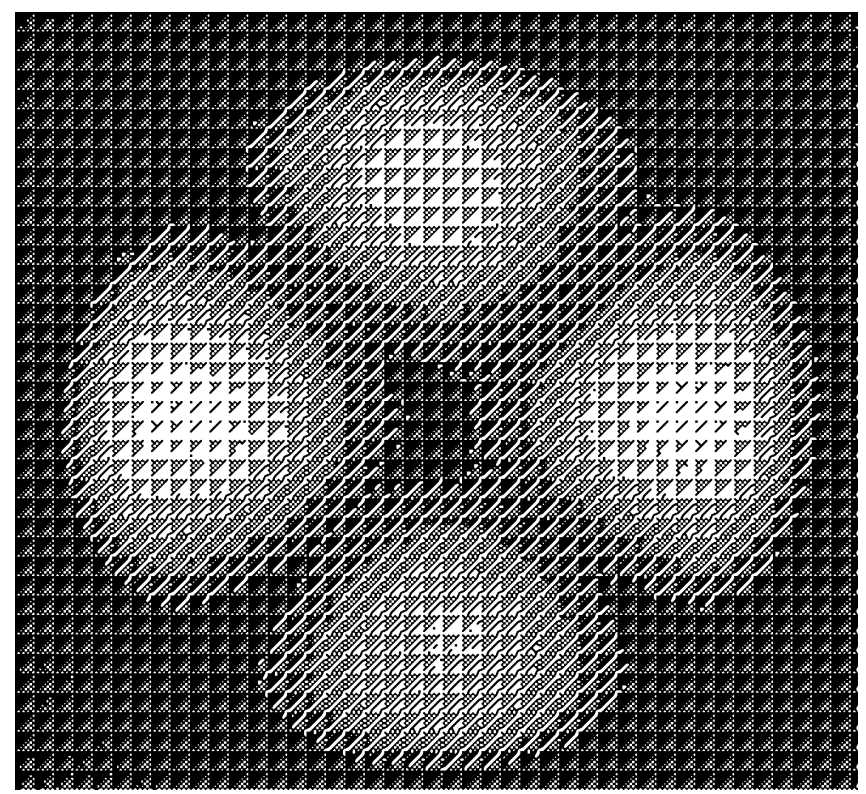

Fig. 1. Typical conoscopic picture of a uniaxial crystal observed for the studied glasses during the experiment which indicates a homeotropic alignment

temperature of the phase transition "crystal-liquid crystal") using both the capillary technique $[11,12]$ and the crushing method. After the melting to the liquid crystal state, all samples were cooled to achieve the glass state. It was found (using the method of polarizing microscopy) that all studied materials are homeotropically aligned at non-treated glass substrates.

\section{Experimental Methods}

Thermal polarizing optical microscopy complemented with the improved conoscopic method were used in order to provide the basic optical characterization of cobaltalkanoate mesomorphic glasses [13,14]. In this way, such characteristics as alignment, pretilt angle, and optical quality were measured.

Electronic spectroscopy was used to measure the absorption spectra of mesomorphic glasses in the visible optical diapason $(400-700 \mathrm{~nm})$.

Nonlinear-optical properties of the mesomorphic glasses were studied, by using the method of laserinduced dynamic gratings [15, 16]. Measurements were made using the second harmonic of a pulsed Qswitched Nd:YAP laser $\left(\mathrm{TEM}_{00}\right.$-mode, wavelength $\lambda=$ $539.8 \mathrm{~nm}$, pulse duration $t_{p}=20 \mathrm{~ns}$, and the pulse frequency $\nu=3 \mathrm{~Hz}$ ) as a source of the intense coherent radiation. Recorded gratings were investigated in the self-diffraction regime via measuring the diffrac-

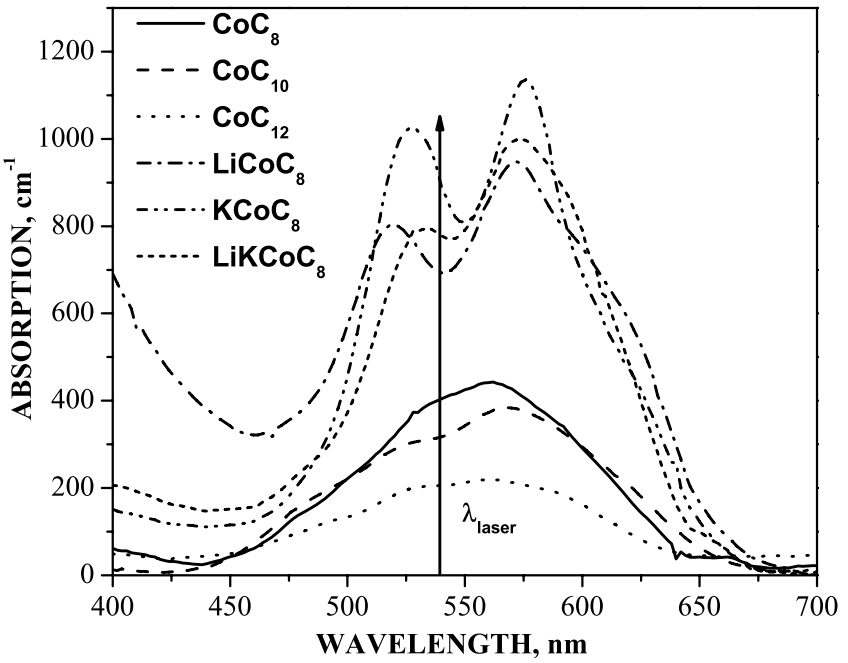

Fig. 2. Absorption spectra of the mesomorphic glasses measured at room temperature. Arrow indicates the wavelength $(539.8 \mathrm{~nm})$ of a pulsed laser used in experiments

tion efficiency $\eta$ ( $\eta$ can be defined as the ratio of the intensity of the first-order diffracted laser beam $I_{+1}$ to the intensity of the incident laser beam $I_{0.1}$ : $\left.\eta=\left(I_{+1}\right) /\left(I_{0.1}\right)\right)$.

\section{Experimental Results and Discussions}

\subsection{Conoscopic characterization}

The improved conoscopic method was used to confirm anisotropic properties of the studied mesomorphic glasses and to determine their birefringence. A typical conoscopic picture of the uniaxial crystal observed for the studied glasses is shown in Fig. 1. Such a result clearly indicates the anisotropic optical properties (optical birefringence) of the mesomorphic glasses and their homeotropic alignment. It was also found (using the crystal rotation method) that the pretilt angle of molecules of a mesomorphic glass cell is in the range $89.9^{\circ}-9.5^{\circ}$ (homeotropic alignment).

\subsection{Absorption spectra}

All studied mesomorphic glasses absorb light in the visible optical diapason (500-600 nm, see Fig. 2). The observed spectrum can be considered in terms of ligand field theory $[17,18]$, as the excitation of cobalt octahedral and tetrahedral complexes. The presence of a broad absorption band with unresolved structure in the cobalt alkanoate mesomorphic glass indicates the coexistence of several coordination forms of $\mathrm{Co}^{2+}$ ions: 


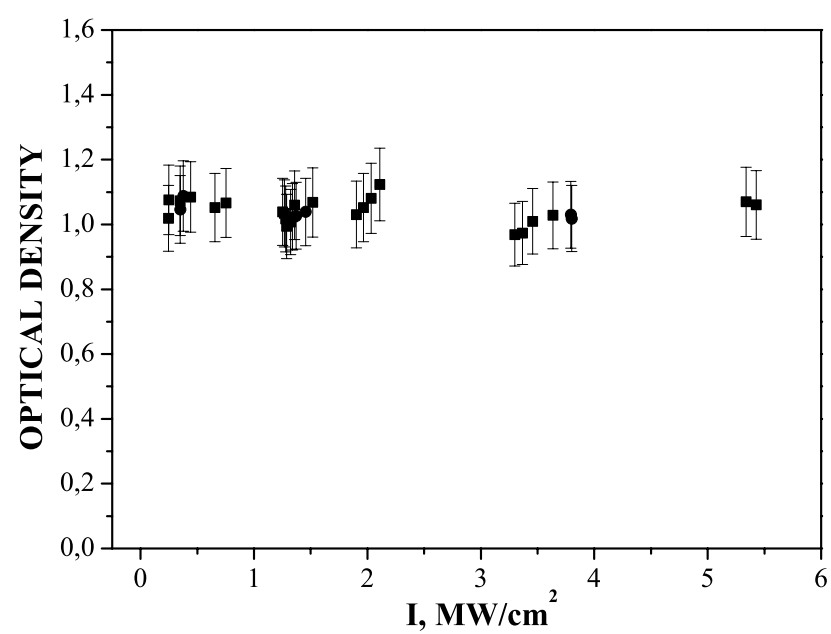

Fig. 3. Typical dependence of the optical density of the mesomorphic glasses on the laser beam intensity for the studied mesomorphic glasses

- the bands with maxima at $530 \mathrm{~nm}\left({ }^{4} T_{1 g}\left({ }^{4} F\right) \rightarrow{ }^{4}\right.$ $T_{1 g}\left({ }^{4} P\right)$ transition $)$ and $565 \mathrm{~nm}\left({ }^{4} T_{1 g}\left({ }^{4} F\right) \rightarrow{ }^{4} A_{2 g}\left({ }^{4} F\right)\right.$ transition) are typical of octahedrally coordinated $\mathrm{Co}^{2+}$ ions;

- in the case of binary systems, the band with a maximum at $620 \mathrm{~nm}\left({ }^{4} A_{2}\left({ }^{4} F\right) \rightarrow{ }^{4} T_{1}\left({ }^{4} P\right)\right.$ transition $)$ is observed, which is typical of tetrahedral complexes.

\subsection{Nonlinear transmission and third-order nonlinear-optical response of the mesomorphic glasses}

It is found that the optical density $D$ of all studied mesomorphic glasses does not depend on the intensity $I$ of a laser beam (Fig. 3). So, only the linear absorbance of a laser beam should be taken into consideration, by analyzing the experimental results described below.

It is found that all studied materials demonstrate the quadratic dependence of the self-diffraction efficiency versus the intensity: $\eta \sim I^{2}$ (Fig. 4). Such a dependence indicates the cubic nonlinear-optical response of all studied materials at the nanosecond time diapason.

Studying the erasure kinetics of residual thermal gratings in the microsecond diapason shows the exponential time dependence of the diffraction efficiency in the first diffraction order (Fig. 5). Such a dependence is characteristic of thermal gratings. But, comparing the thermal grating diffraction efficiency $\eta_{T}$ with the diffraction efficiency of a grating recorded in the mode of selfdiffraction $\eta$ shows that $\eta_{T} \ll \eta\left(\eta / \eta_{T} \approx 100\right)$.

Laser-induced changes in the refractive index $\Delta n$ are proportional to the incidence laser beam intensity $I$ :

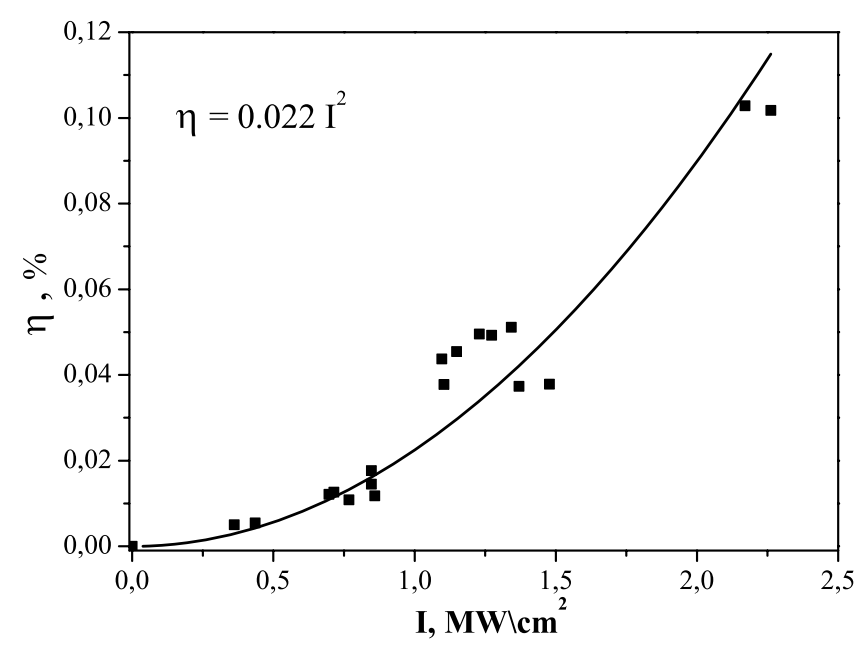

Fig. 4. Typical dependence of the self-diffraction efficiency versus the intensity of incident laser beams for studied mesomorphic glasses

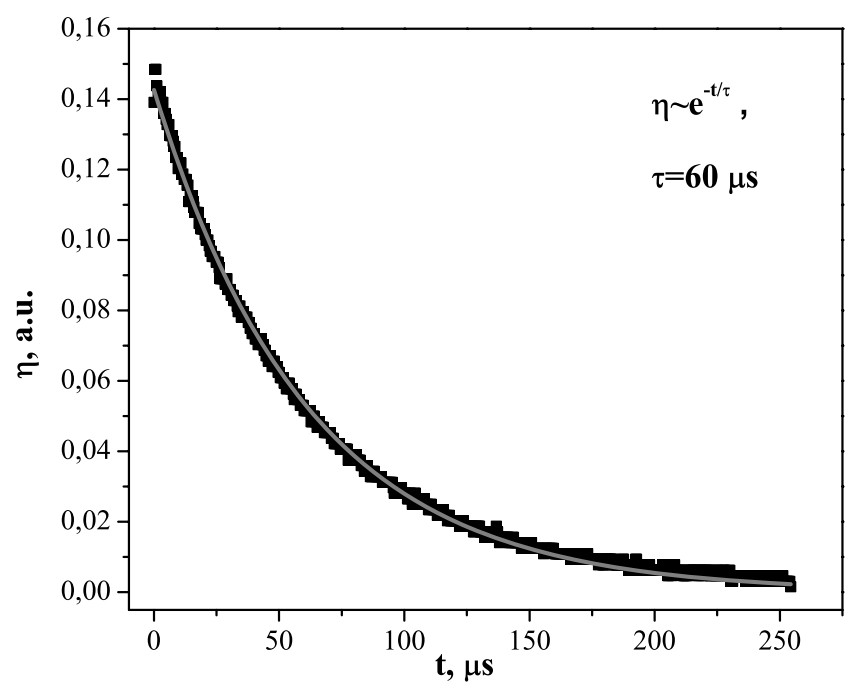

Fig. 5. Typical time dependence of the residual thermal gratings diffraction efficiency for studied mesomorphic glasses

$\Delta n=n_{2} I$, where $n_{2}$ - nonlinear refractive index which is a macroscopic characteristic of the nonlinear-optical properties of the materials. The nonlinear refractive index can be extracted from the measured values of the self-diffraction efficiency, as it is described in works $[12,16]$ :

$n_{2}=\frac{\lambda}{\pi d_{\mathrm{eff}} I_{0}} \sqrt{\frac{\eta}{T}}$.

Here, $\lambda$ - wavelength of a laser beam, $d_{\text {eff }}$ - effective cell thickness, and $T$ - transmission. In the case of dynamic gratings, $I_{0}=m\left(I_{1}+I_{2}\right)$, where $m=\frac{2 \sqrt{I_{1} I_{2}}}{I_{1}+I_{2}}, I_{1}$ and 
$I_{2}$ are the intensities of beams which interfere on the investigated sample, and $m$ - modulation depth. The nonlinear refractive indices of the all studied mesomorphic glasses are collected in Table 1.

The third-order nonlinear-optical response can be caused by various physical mechanisms (e.g., nonlinear electronic polarization, thermal heating, electrostriction, molecular reorientation, etc.) $[15,16]$. Therefore, the measured value of nonlinear refractive index can be considered as a sum of actual nonlinear refractive indices (each additive in this sum corresponds to a definite physical mechanism).

Cobalt-alkanoate complexes (tetrahedral and octahedral coordinations [17]) can be considered as anharmonic oscillators under applying the external electromagnetic field (mechanism of electronic hyperpolarizability). Such changes in the electronic polarizability of the cobaltalkanoate complexes can give rise to the third-order nonlinear-optical response.

In addition to the mechanisms of third-order optical nonlinearity described above (changes in the electronic polarizability of cobalt ions under the action of an external electro-magnetic field), the thermal optical nonlinearity also should be taken into consideration, since all studied materials consisting of cobalt complexes absorb light at the laser wavelength (see Fig. 2). So, the measured value of nonlinear refractive index $n_{2}$ is the sum of two main additives: the first of them $n_{2}$ is of the electronic origin, and the second one $n_{2}^{\text {thermal\} }}$ is of the thermal origin. The next step is to separate the contributions of these considered mechanisms to the measured nonlinear-optical response of smectic glasses.

\subsection{Thermal optical nonlinearity}

As was mentioned above, in the case of absorbing materials, the thermal optical nonlinearity can contribute to the measured value of $n_{2}$ or $\Delta n=n_{2} I$ :

$\Delta n=\Delta n_{\text {electronic }}+\Delta n_{\text {thermal }}$,

$\Delta n_{\text {thermal }}=\frac{d n}{d T} \Delta T$

Let us estimate the contribution of the thermal optical nonlinearity $n_{2}^{\text {thermal }}$ to the measured value of $n_{2}$. As can be shown [12,19-21], the nonlinear refractive index $n_{2}^{\{\text {thermal }}$ caused by the thermal optical nonlinearity can be found as follows:

$n_{2}^{\{\text {thermal }\}}=\frac{d n}{d T} \frac{\alpha}{c_{p} \rho} t_{p}$.
Here, $\frac{d n}{d T}-$ thermo-optical constant, $\rho$ - density, $c_{p}-$ specific heat capacity, $t_{p}$ - time duration of a laser pulse, and $\alpha$ - linear absorption coefficient.

Using this expression, one can estimate the nonlinear refractive indices caused by only the thermal optical nonlinearity (thermal nonlinear refractive indices) for studied materials (Table 1). In such a way, we estimated the value of $n_{2}^{\{\text {thermal }}$ for mesomorphic glasses to be of the order of $10^{-13} \mathrm{~cm}^{2} / \mathrm{W}$. The experimental value $\left(\sim 10^{-10}\right.$ $\left.\mathrm{cm}^{2} / \mathrm{W}\right)$ is by two orders larger than the estimated one. Such a disagreement between the estimation and the experiment allows us to neglect thermal optical nonlinearities on the nanosecond time scale and to consider only the electronic nonlinearity.

\subsection{Electronic optical nonlinearity}

The macroscopic (third-order electronic susceptibility $\chi^{(3)}$ ) and microscopic (hyperpolarizability $\gamma_{\mathrm{NL}}$ ) nonlinear-optical parameters of the studied mesomorphic glasses can be found, by using the expressions presented below $[15,16]$ :

$\chi^{(3)}=\varepsilon_{0} c n^{2} n_{2}=\gamma_{\mathrm{NL}} N L^{4}$

Here, $\varepsilon_{0}$ - electric constant, $n$ - refractive index, $c-$ light velocity, $L$ - local field factor (for simplicity, we will use the Lorentz local field factor $L=\frac{n^{2}+2}{3}$ ), and $N$ - concentration of the nonlinear-optical active cobalt complexes. Using the above-mentioned expressions, the basic nonlinear-optical parameters were extracted from experimental data (Table 2).

\subsection{Tuning of the nonlinear-optical properties of the cobalt-alkanoates mesomorphic glasses}

As can be seen from Table 2, the susceptibilities $\chi^{(3)}$ of the cobalt-alkanoates mesomorphic glasses are decreasing with increasing the anion length (or smectic bilayer spacing) from $6.65 \times 10^{-16}$ to $2.64 \times 10^{-16} \mathrm{~m}^{2} \mathrm{~V}^{-2}$. Such a decrease is caused mainly by three factors: 1) decrease

T a b l e 1. Nonlinear refractive indices of mesomorphic glasses

\begin{tabular}{|c|c|c|c|}
\hline & $\mathrm{CoC}_{8}$ & $\mathrm{CoC}_{10}$ & $\mathrm{CoC}_{12}$ \\
\hline$n_{2}, \mathrm{~cm}^{2} / \mathrm{W}$ & $11.2 \times 10^{-10}$ & $8.3 \times 10^{-10}$ & $4.5 \times 10^{-10}$ \\
\hline \multirow[t]{2}{*}{$n_{2}^{\{\text {thermal }\}}, \mathrm{cm}^{2} / \mathrm{W}$} & $1.38 \times 10^{-12}$ & $1.14 \times 10^{-12}$ & $0.86 \times 10^{-12}$ \\
\hline & $\mathrm{CoC}_{8}: \mathrm{LiC}_{8}$ & $\mathrm{CoC}_{8}: \mathrm{KC}_{8}$ & $\mathrm{CoC}_{8}: \mathrm{LiC}_{8}: \mathrm{KC}_{8}$ \\
\hline$n_{2}, \mathrm{~cm}^{2} / \mathrm{W}$ & $4.6 \times 10^{-10}$ & $5.3 \times 10^{-10}$ & $4.6 \times 10^{-10}$ \\
\hline$n_{2}^{\{\text {thermal }\}}, \mathrm{cm}^{2} / \mathrm{W}$ & $2.43 \times 10^{-12}$ & $3.04 \times 10^{-12}$ & $2.68 \times 10^{-12}$ \\
\hline
\end{tabular}


of the concentration $N$ of the nonlinear-optical centers (cobalt complexes), 2) decrease of the local field factor $L$, 3 ) decrease of the hyperpolarizability $\gamma_{\mathrm{NL}}-$ microscopic characteristics of the nonlinear-optical centers. For such homologous series, the local factor does not contribute sufficiently to the observed decrease of $\chi^{(3)}$ (linear refractive indices of these mesomorphic glasses change very slightly, and, therefore, the local field factor $L$ cannot affect $\left.\chi^{(3)}\right)$. So, a decrease of the concentration $N$ and $\gamma_{\mathrm{NL}}$ are the main factors, which affect the observed decrease of $\chi^{(3)}$ (Table 2).

As was mentioned above, the decrease of $\chi^{(3)}$ correlates with decreasing the concentrations of cobalt complexes. Additionally, it should be noted that the thirdorder nonlinear optical response of the studied mesomorphic glasses is also affected via interactions of a cobalt ion (coordination center of complex) with the counterion surrounding (carboxyl groups of alkanoate-anions).

\section{Conclusions}

We have presented the results of systematic studies of the nonlinear-optical properties of the mesomorphic glasses based on cobalt-alkanoate. It is found that such rigid glasses with intrinsic layered structure demonstrate the enhanced third-order nonlinear-optical response $\left(\chi^{(3)} \sim 10^{-8} \mathrm{esu}\right)$ of the electronic origin (mechanism of laser-induced electronic nonlinear polarization) on the nanosecond time scale. It is shown that the thermal optical nonlinearity can be neglected on the nanosecond time scale for these materials. Based on this, the main nonlinear-optical parameters $\left(\chi^{(3)}, \gamma_{\mathrm{NL}}\right)$ are recalculated.

It is found that the nonlinear-optical response of the cobalt-containing mesomorphic layered glasses is caused by cobalt-alkanoate complexes as main nonlinear-optical centers, which are arranged into spatial ordered twodimensional layers. The basic third-order nonlinear-

T a b l e 2. Basic nonlinear-optical parameters of the mesomorphic glasses

\begin{tabular}{ccccc}
\hline & $\mathrm{CoC}_{8}$ & $\mathrm{CoC}_{10}$ & $\mathrm{CoC}_{12}$ \\
\hline$\chi^{(3)}, \mathrm{m}^{2} \cdot \mathrm{V}^{-2}$ & $6.65 \times 10^{-16}$ & $4.92 \times 10^{-16}$ & $2.64 \times 10^{-16}$ \\
$\chi^{(3)}, \mathrm{esu}$ & $4.8 \times 10^{-8}$ & $3.5 \times 10^{-8}$ & $1.9 \times 10^{-8}$ \\
$\gamma_{\mathrm{NL}}, \mathrm{m}^{2} \cdot \mathrm{V}^{-2}$ & $8.4 \times 10^{-44}$ & $7.4 \times 10^{-44}$ & $4.9 \times 10^{-44}$ \\
$\gamma_{\mathrm{NL}}, \mathrm{esu}$ & $6.0 \times 10^{-30}$ & $5.3 \times 10^{-30}$ & $3.5 \times 10^{-30}$ \\
\hline & $\mathrm{CoC}_{8}: \mathrm{LiC}_{8}$ & $\mathrm{CoC}_{8}: \mathrm{KC}_{8}$ & $\mathrm{CoC}_{8}: \mathrm{LiC}_{8}: \mathrm{KC}_{8}$ \\
\hline$\chi^{(3)}, \mathrm{m}^{2} \cdot \mathrm{V}^{-2}$ & $2.76 \times 10^{-16}$ & $3.1 \times 10^{-16}$ & $2.74 \times 10^{-16}$ \\
$\chi^{(3)}, \mathrm{esu}$ & $1.98 \times 10^{-8}$ & $2.25 \times 10^{-8}$ & $1.96 \times 10^{-8}$ \\
$\gamma_{\mathrm{NL}}, \mathrm{m}^{2} \cdot \mathrm{V}^{-2}$ & $4.9 \times 10^{-44}$ & $5.9 \times 10^{-44}$ & $5.0 \times 10^{-44}$ \\
$\gamma_{\mathrm{NL}}, \mathrm{esu}$ & $3.5 \times 10^{-30}$ & $4.2 \times 10^{-30}$ & $3.6 \times 10^{-30}$ \\
\hline
\end{tabular}

optical parameters $\left(\chi^{(3)}\right.$ and $\left.\gamma_{\mathrm{NL}}\right)$ depend on the cobalt alkanoate concentration (this factor is dominant) and are affected by interactions between cobalt ions and alkanoate-anions (in the case of pure cobalt-alkanoate glasses) or between metal cations and alkanoate-ions (for binary and ternary systems).

Finally, the anisotropic mesomorphic glasses based on cobalt-alkanoates represent a novel type of tunable optical and nonlinear-optical materials: their fundamental physical properties (nonlinear $n_{2}$ refractive index, thirdorder susceptibility $\chi^{(3)}$, and molecular hyperpolarizability $\gamma_{\mathrm{NL}}$ ) can be tuned via changing the alkanoate-anion length and by varying the cation composition. Such simple ways open a new avenue in the field of the optical and nonlinear-optical material design.

1. K. Binnemans, Chem. Rev. 105 (11), 4148 (2005).

2. T.A. Mirnaya and S. Volkov, in Green Industrial Applications of Ionic Liquids, edited by R.D. Rogers, K.R. Snedon, and S. Volkov (Kluwer, Dordrecht, 2003), p. 439.

3. T.A. Mirnaya, V. Prisyazhnyi, and V. Shcherbakov, Rus. Chem. Rev. 58, 821 (1989).

4. Polishchuk and T. Timofeeva, Rus. Chem. Rev. 62, 291 (1993).

5. Bordyuh, Yu. Garbovskiy, S. Bugaychuk, G. Klimusheva, and V. Reshetnyak, Mol. Crys. and Liq. Crys. 508, 296 (2009)

6. A.B. Bordyuh, Yu. Garbovskiy, S. Bugaychuk, G. Klimusheva, T.A. Mirnaya, G. Yaremchuk, and A. Polyshchuk, Opt. Mat. 31, 1108 (2009).

7. S.A. Bugaychuk, G. Klimusheva, Yu. Garbovskiy, T. Mirnaya, and A. Ischenko, Opt.-El. Rev. 14, 275 (2006).

8. G.V. Klimusheva, S. Bugaychuk, Yu. Garbovskiy, O. Kolesnik, T.A. Mirnaya, and A. Ishchenko, Opt. Lett. 31, 235 (2006).

9. S. Bugaychuk, Yu. Garbovskiy, G. Klimusheva, and T. Mirnaya, in Proceedings of the 4th International Conference on Advanced Optoelectronics and Lasers (2008), p. 120.

10. Transition Metal and Rare Earth Compounds III: Excited States, Transitions, Interactions, edited by H. Yersin (Springer, Berlin, 2004).

11. A.V. Grydyakina, G.V. Klimusheva, A.P. Polishchuk, A.V. Koval'chuk, A.S. Tolochko, T.A. Mirnaya, and L.S. Sudovtsova, Rus. J. Phys. Chem. 79 (Suppl. 1), 871 (2005).

12. Yu.A. Garbovskiy, A.V. Gridyakina, G.V. Klimusheva, A.S. Tolochko, I.I. Tokmenko, and T.A. Mirnaya, Liq. Crys. 37, 1411 (2010).

13. T. Uchida and H. Seki, Surface Alignment of Liquid Crystals (World Scientific, Singapore, 1992). 
14. S. Kumar, Liquid Crystals: Experimental Studies of Physical Properties and Phase Transitions (Cambridge Univ. Press, Cambridge, 2000).

15. M.G. Kusyk and C. Dirk, Characterization Techniques and Tabulations for Organic Nonlinear Optical Materials (M. Dekker, New York, 1998).

16. H.J. Eichler, P. Gunter, and D.W. Pohl, Laser-Induced Dynamic Gratings (Springer, Berlin, Heidelberg, 1986).

17. S.V. Volkov and K.B. Yatsimirskii, Spectroscopy of Molten Salts [in Russian] (Naukova Dumka, Kiev, 1977).

18. E. Crabb, E. Moore, and L. Smart, Concepts in Transition Metal Chemistry (Royal Soc. of Chemistry, London, 2010).

19. R.W. Boyd, Nonlinear Optics (Academic Press, San Diego, 2003).

20. I.C. Khoo, Liquid Crystals: Physical and Nonlinear Optical Phenomena (Wiley, New York, 1995).

21. I.C. Khoo, Phys. Rep. 471, 221 (2009).

Received 22.09.11

\section{НЕЛІНІЙНИЙ ОПТИЧНИЙ ВІДГУК СМЕКТИЧНИХ СТЕКОЛ НА ОСНОВІ АЛКАНОАТІВ КОБАЛЬТУ}

О.В. Грідякіна, Ю.А. Гарбовсъкий, Г.В. Клімушева, А.П. Поліщук

$\mathrm{P}$ е $з$ ю м е

У даній роботі наведено результати експериментальних досліджень оптичних та нелінійно-оптичних властивостей мезоморфних стекол алканоатів кобальту. Показано, що досліджені мезоморфні стекла мають чітку гомеотропну орієнтацію молекул та структуру смектичного кристала. При вивченні спектрів поглинання, виявлено, що у мезоморфному склі присутні октаедрична та тетраедрична координації іонів $\mathrm{Co}^{2+}$. Реалізовано та досліджено голографічний запис тонких динамічних граток у мезоморфних стеклах алканоатів кобальту. Записані гратки характеризуються високими значеннями кубічної діелектричної сприйнятливості $\chi^{(3)}$, гіперполяризованості $\gamma_{\mathrm{NL}}$, коефіцієнта нелінійної рефракції $n_{2}$ та мають мікросекундні часи релаксації. Запропоновано фізичний механізм запису, що зумовлений нелінійною електронною поляризованістю, викликаною дією інтенсивного лазерного випромінювання на комплекси катіонів кобальту. 